\title{
Market Concentration and Efficiency of Indian Commercial Banks
}

\author{
Jayachitra Thiruvaiyaru Anantharaman ${ }^{1}$, Kallanmarthodi Geetha ${ }^{2}$ \\ ${ }^{1}$ Project Fellow (ICSSR), Department of Economics, Avinashilingam Institute for Home Science and Higher Education for Women, \\ Coimbatore, India \\ ${ }^{2}$ Department of Economics, Avinashilingam Institute for Home Science and Higher Education for Women, Coimbatore, India
}

Email address:

tajbirds@gmail.com (J. T. Anantharaman),k_t_geetha@yahoo.co.in (K. Geetha)

\section{To cite this article:}

Jayachitra Thiruvaiyaru Anantharaman, Kallanmarthodi Geetha. Market Concentration and Efficiency of Indian Commercial Banks. American Journal of Theoretical and Applied Business. Vol. 3, No. 1, 2017, pp. 1-10. doi: 10.11648/j.ajtab.20170301.11

Received: March 6, 2017; Accepted: May 2, 2017; Published: May 22, 2017

\begin{abstract}
The Indian banking industry is going through a period of intense change, where liberalized business environment has affected the banking business by way of increasing competition, rising customer expectations, shrinking spreads and increasing disintermediation. Ongoing changes in the structure of Indian banking are clearly visible. This paper investigates the levels and determinants of efficiency of schedule commercial banks of this vital sector of the Indian economy by using firmlevel data. For this purpose, a two stage data envelopment analysis has been used. In the first stage, super technical efficiency analysis of 89 sample firms has been undertaken. This study specifies two outputs: total loans and other earning assets and three inputs: labour, fixed capital and total customers and short term funding and the prices are personnel expenses to average number of personnel for labour, total capital expenses to total fixed assets for fixed capital and interest expenses to average total customers and short term funding for the years 1980-81 to 2012-13. In the second stage, the efficiency scores obtained from the first stage are regressed on external environmental factors like fiscal deficits, private investment and the share of foreign banks using a censored regression model, viz. Tobit model. In this context, the term environment is used to describe factors that could influence the efficiency of a firm, where such factors are not traditional inputs and are not under the control of management (17). The results confirm that the varying market condition and the presence of foreign banks will contribute positively to economic growth.
\end{abstract}

Keywords: Bank Efficiency, Schedule Commercial Banks, DEA Models

\section{Introduction}

The importance of financial systems for economic development is well recognized worldwide [30, 36, 35, 41] as well as in India [44, 9]. Banks are considered to be the mart of the world, the nerve centre of economies and finance of a nation and the barometer of its economic perspective [51]. Indian banking sector is one of the largest sector in Southern Asian continent which is the mixture of public, private and foreign groups. The public sector banks continue to dominate the banking industry, in terms of lending and borrowing, and it has widely spread out branches which help greatly in pooling up of resources as well as in revenue generation for credit creation. The role of banks in accelerating economic development of the country has been increasingly recognized since the nationalization of fourteen major commercial banks in 1969 and six more in 1980. This facilitated the rapid expansion of banking in terms of its geographical reach covering rural India, in turn leading to significant growth in deposits and advances. Eventually, however, the government used banking sector to finance its own deficit by frequently increasing cash reserve ratios (CRR) and statutory liquidity ratio (SLR). This, in turn, affected the resource position of commercial banks adversely, restricting their lending and thereby the ability to generate profits. Besides, inefficiency and lack of competition caused the non-performing assets in the public sector banks to rise from 14 percent in 1969 to 35 percent in 1990. This problem had to be tackled during the 
nineties by undertaking an array of financial reforms.

The invisible handcuff unleashed in the Indian Economy by deregulation of the Indian financial system in 1991 followed by various financial sector reforms during the period 1990 through 1998 led to a major restructuring of the Indian banking industry. Reforms have altered the organizational structure, ownership pattern and domain of operations of institutions and infused competition in the financial sector. The competition has forced the institutions to reposition themselves in order to survive and grow. These reforms are expected to have an impact on the operations of commercial banks. Also, one of the important objectives of financial sector reforms was to improve the efficiency of banking system [42]. Thus it is essential to study the efficiency levels of Indian commercial banks to understand the impact of financial sector reforms on its performance. The study dealt with the efficiency and performance of Indian commercial banks according to its ownership structure and further evaluated banking sector reforms since globalization.

\section{Brief Literature Review}

A number of attempts have been made to study the efficiency and productivity of banking sector in developed countries [7, 8, 24, 61]. However, studies analyzing the efficiency of banks in developing countries, including India, are relatively modest. Most of the literature in Indian banking sector focused on measurement of efficiency (e.g., [13, 45, $47,46,71]$ and a few studies on benchmarking (e.g., [23, 65]. While some studies attribute the growth of productivity to technological progress $[4,2,39,10,29,54]$, others are in favour of efficiency improvement [6, 22, 25, 72]. Compared to efficiency analysis, the literature on the issue of TFP growth in Indian banking sector is very limited. The study investigated the efficiency and productivity for a sample of Indian commercial banks over the period 1995-2002 by using the technique of DEA [20]. However, studies of the efficiency market power relationship in emerging markets have been considerably less rigorous, lacking in detailed studies of the determinants of bank technical efficiency. This paper fills the gap by widening the scope in explanatory variables not only market structure, but also other factors such as bank sector reforms which had the string impact in the financial market performance and macroeconomic conditions. The current study contributes to the literature significantly in many ways. A detailed systematic study on the measurement of productivity change in Indian banking sector was comparatively limited. Secondly, in comparison to previous studies (e.g., [20, 65, 63,71] this study considers more recent data for a relatively longer period of latest 15 years of post-liberalization which includes 3 years of global financial crisis period. Also, one of the important objectives of financial sector reforms was to improve the efficiency of banking system [42]. Thus it is essential to study the efficiency levels of Indian commercial banks to understand the impact of financial sector reforms on its performance.

\section{Objectives}

To determine the impact of various market and regulatory initiatives on efficiency improvements of commercial banks since the implementation of financial sector reforms.

Hypothesis

The reform measures have not caused an improvement in the efficiency level across different bank groups.

\section{Methodological}

The Indian banking sector provides a particularly interesting setting to examine the impact of liberalisation on the banking firms. The banking sector in India comprises of domestic banks, which includes public sector banks and privatively owned banks as well as foreign banks. Presently, there are 43 Foreign Banks, 26 Public Sector Banks and 20 Private Sector Banks [42]. The research was based on the secondary data and the main stream of data was collected from the - Statistical Tables Relating to Commercial Banks in India, Annual Accounts of Scheduled Commercial Banks', Annual Reports, authentic records and publications of RBI and website of individual banks and RBI website. Data on GDP was collected from Handbook of Statistics on the Indian Economy published by the RBI. All the variables have been adjusted to the Indian GDP deflator and converted to constant prices (2004-05 prices). Since the research was based on the time series cross section secondary data and quantitative in nature, the analysis of the data was undertaken by applying the DEA analysis and regression analysis. Before doing the computations, the stationarity of each series was tested using the Augmented Dickey-Fuller test.

\subsection{Variable Description}

Although there is no 'perfect approach', the intermediation approach may be more appropriate for evaluating entire financial institutions because this approach is inclusive of interest expenses, which often account for one-half to twothirds of total costs [6]. Moreover, the intermediation approach may be superior for evaluating the importance of frontier efficiency of financial institutions. The main consequence of the intermediation approach is that deposits are considered as inputs, and interest on deposits is a component of total costs, together with labour and capital costs.

Table 1. Variables used for estimation.

\begin{tabular}{lll}
\hline Variable & Terminology & Description \\
\hline Output & Total loan & Loans issued \\
Output & Other earning assets & Sum of investment securities \\
Input & Labour & Number of full-time employees \\
Input & Fixed capital & Fixed Assets (Property and \\
& Customer and short-term & Equipment) \\
Input & Deposits and current accounts \\
\hline
\end{tabular}

Accordingly, this study specifies two outputs: total loans and other earning assets and three inputs: labour, fixed 
capital and total customers and short term funding and the prices are personnel expenses to average number of personnel for labour, total capital expenses to total fixed assets for fixed capital and interest expenses to average total customers and short term funding for total customers and short term funding. This assumption on outputs is consistent with studies [19, 31, and 59]. Other assets as a third output, was excluded in this study as atleast two of the banks did not have any values recorded for these variables. Since the model variables are in logarithms, this would have introduced an error in the inputs, hence the exclusion. Table 1 outlines the data extracted from the bank's Annual Reports that were used in the estimation of frontiers.

\subsection{DEA Modeling}

DEA is a linear programming technique initially developed [11] to evaluate the efficiency of public sector non-profit organizations, based on earlier work initiated [16]. It was later extended [5.52] and to banking. DEA calculates the relative efficiency scores of various Decision-Making Units (DMUs) in the particular sample. The DMUs could be banks or branches of banks. The DEA measure compares each of the banks to branches in that sample with the best practice in the sample. It tells the user which of the DMUs in the sample are efficient and which are not. The ability of the DEA to identify possible peers or role models as well as simple efficiency scores gives it an edge over other methods. As an efficient frontier technique, DEA identifies the inefficiency in a particular DMU by comparing it to similar DMUs regarded as efficient, rather than trying to associate a DMU's performance with statistical averages that may not be applicable to that DMU.

An 'enhanced decomposition', which takes the efficiency change component calculated relative to the constant returns to scale (CRS) technology and further decomposes into a 'pure technical efficiency change' component (calculated relative to the variable returns to scale (VRS) technology) and a residual 'scale efficiency' component, which captures changes in the deviation between the VRS and CRS technologies. The decomposition becomes, [15]

$$
\mathrm{M}_{0}\left(\mathrm{y}_{\mathrm{s}}, \mathrm{x}_{\mathrm{s}}, \mathrm{y}_{\mathrm{t}}, \mathrm{x}_{\mathrm{t}}\right)=\mathrm{TC} \times \mathrm{TE} \times \mathrm{SE}
$$

where TC represents Technical Change, TE represents pure efficiency change and SE represents scale change. The scale change and pure efficiency change components are the decomposition of the efficiency component TEC $=\mathrm{TE} \times \mathrm{SE}$. DEA modeling allows the analyst to select inputs and outputs in accordance with managerial focus. This is an advantage of DEA since it opens the door to what-if analysis. Furthermore, the technique works with variables of different units without the need for standardisation (e.g. dollars, number of transactions, or number of staff). The approach used in this study was variation of the intermediation approach. The input variables used in this study are labour, fixed capital, customer and short-term funding funds and the output variables are total loans and other earning assets. Appropriate GDP deflators have been used to deflate the values. [15]

\subsection{Constant Returns to Scale (CRS or CCR)}

A model [11] proposed which had input orientation and assumed constant return to scale (CRS). Assume that there are $n$ DMUs consuming varying amounts of $k$ different inputs to produce $\mathrm{m}$ different outputs. Specifically, $D M U_{i}$ are represented by $\mathrm{x}_{\mathrm{i}}$ and $\mathrm{y}_{\mathrm{i}}$ respectively. The $\mathrm{K} \times \mathrm{N}$ input matrix, $\mathrm{X}$ and $\mathrm{M} \times \mathrm{N}$ output matrix $\mathrm{Y}$ represent the data of $\mathrm{N}$ firms. The purpose of DEA was to construct the frontier that the observed data lie on or below the production frontier. For each DMU a measured ratio of all outputs (y) over all inputs (x), such as $u^{\prime} y / v ' x$, where $u$ is output weight and $v$ is input weight. To select optimal weights, the mathematical programming problem:

$$
\begin{gathered}
\operatorname{Max}_{u v}\left(u^{\prime} y_{i} / v^{\prime} x_{i}\right) \\
\text { s.t u' } y_{j} / v^{\prime} x_{j} \leq 1 j=1,2, \ldots . N \\
u, v \geq 0
\end{gathered}
$$

The finding values for $\mathrm{u}$ and $\mathrm{v}$, such that the efficiency measure of the ith DMU is maximised, subject to the constraint that all efficiency measures must be less than or equal to one. One problem with this particular ratio formulation is that it has an infinite number of solutions. To avoid this, an equivalent envelopment form of this problem is estimated, i.e.

$$
\begin{gathered}
\operatorname{Min}_{\theta, \lambda} \theta \\
\text { s.t }-\mathrm{y}_{\mathrm{i}}+\mathrm{y} \lambda \geq 0 \\
\theta \mathrm{x}_{\mathrm{i}}-\mathrm{X} \lambda \geq 0 \\
\lambda \geq 0
\end{gathered}
$$

The value of $\theta$ obtained will be the efficiency score of ith DMU. It will satisfy $\theta \leq 1$, with a value of 1 indicating the point on the frontier and technical efficient DMU.

\subsection{Super Efficiency}

Andersen and Petersen's model for estimating superefficiency score for DMU $k$ (denoted by $\mathrm{TE}^{\mathrm{k} \text {, super }}$

$$
\begin{gathered}
\mathrm{TE}^{\mathrm{k}, \text { super }}=\theta_{k}^{\text {super }}-\varepsilon^{\left[\sum_{i=1}^{m} s_{i}^{-}+\sum_{i=1}^{m} s_{r}^{+}\right]} \\
\operatorname{Min}^{=} \theta_{k}^{\text {super }}, \lambda, s_{i}^{-}, s_{r}^{+}
\end{gathered}
$$

Subject to

$$
\begin{gathered}
\sum_{j=1, j=k}^{m} \lambda_{j} y_{r j}-s_{r}^{+}=y_{r} \\
\mathrm{r}=1,2 \ldots \mathrm{s} \\
\sum_{j=1, j=k}^{m} \lambda_{j} \mathrm{x}_{r j}+s_{r}^{-}={ }^{=} \theta_{k}^{\text {super }} x_{\mathrm{ik}} \\
\mathrm{r}=1,2 \ldots \mathrm{m} \\
s_{i}^{-}, s_{r}^{+} \geq 0
\end{gathered}
$$




$$
\begin{gathered}
\lambda_{\mathrm{j}}(\mathrm{j}=\mathrm{k}) \geq 0, \\
\mathrm{j}=1,2, \ldots \mathrm{n} .
\end{gathered}
$$

The difference between Super-efficiency model and standard efficiency model is that in super models the $\mathrm{DMU}_{0}$ (the DMU evaluated) is eliminated from the reference set (indicated by $\mathrm{j} \neq 0$ in the LP). The Super-efficiency score can be greater than 1 .

\section{Efficiency and Impact of Market Conditions}

The banks are not only affected by the internal environment but also influenced by the macroeconomic conditions of the country. Thus it is important to measure the impact of the macroeconomic factors which are not under the control of management and financial markets on the performance of the banks. The study employs environmental

$$
\mathrm{TE}=\beta 0+\beta 1 \mathrm{FD}+\beta 2 \mathrm{PI}+\beta 3 \mathrm{FOG}+\beta
$$

$\mathrm{TE}=$ Super-technical efficiency from DEA model

$\mathrm{FD}=$ Fiscal deficit as a percentage to GDP

$\mathrm{PI}=$ Private investment

FOG $=$ Share of foreign banks in total credit

$\mathrm{T} 1=$ Dummy for periodisation 1997

$\mathrm{T} 2$ = Dummy for periodisation 2002

$\mathrm{T} 3=$ Dummy for periodisation 2006

$\beta 0=$ Intercept, $\beta=$ Coefficients of regression parameters, $\varepsilon=$ standard error.

The study expects an increase in PI and FOG to increase bank efficiency and an increase in FD to reduce efficiency, since the presence of high fiscal deficits acts as a key constraint on government's ability to lower high cash reserve requirement imposed on banks [1]. With regard to the private investment and foreign share, the growth in the demand for product or service will induce the investors to invest in that industry which in turn will enhance the efficiency of the firm. Prior to reform there were restriction (entry barrier) made by the government for private investments. Since liberalization the increase in the demand of loans and advance will engage banks in incorporating new technologies that increase their efficiency. While dealing with efficiency variable, the extant literature suggests that such improvements of the banking industry was driven through the technological improvement which lead to the increase in the best practice of productivity and as peer pressure amongst banks compels them to raise

\begin{tabular}{|c|c|c|c|c|}
\hline Variable & Coefficient & Std. Error & t-Statistic & Prob. \\
\hline & $1981-1996--16$ obs & & & \\
\hline $\mathrm{C}$ & 27.17233 & 2.729803 & 9.953953 & 0.0000 \\
\hline YEAR & $\begin{array}{l}-0.0113740 .001374 \\
1997-2001-5 \text { obs }\end{array}$ & & -8.279165 & 0.0000 \\
\hline $\mathrm{C}$ & -142.0604 & 58.52253 & -2.427447 & 0.0227 \\
\hline YEAR & $\begin{array}{l}0.073277 \\
2002-2005--4 \text { obs }\end{array}$ & 0.029264 & 2.504006 & 0.0192 \\
\hline
\end{tabular}
productivity levels.

Table 2. Periodisation of time period. variables to the basic DEA model of super-technical efficiency. The efficiency of banks in the context of these models refers to their ability to utilise operating expenses and interest expenses to generate earning asset. The external environmental factors in the model include: fiscal deficits as a percentage of GDP (FD), private investment as a percentage of GDP (PI) and the share of foreign banks in total credit (FOG) representing the presence of foreign banks. Efficiency of banking assumes significant importance in the context of financial sector reforms, which have resulted in positioning stringent supervisory norms on the lines of international best practice to ensure banking soundness. In the study, the basic DEA model was extended to take into account environmental variables. In this context, the term environment is used to describe factors that could influence the efficiency of a firm, where such factors are not traditional inputs and are not under the control of management [17]. Thus the proposed model was

\begin{tabular}{|c|c|c|c|c|c|}
\hline Variable & \multicolumn{2}{|c|}{ Coefficient } & Std. Error & t-Statistic & Prob. \\
\hline $\mathrm{C}$ & \multicolumn{2}{|c|}{-33.38229} & 16.02217 & -2.083507 & 0.0476 \\
\hline YEAR & \multicolumn{2}{|c|}{$\begin{array}{l}0.018964 \\
2006-2013--8 \text { obs }\end{array}$} & 0.007999 & 2.370697 & 0.0258 \\
\hline $\mathrm{C}$ & \multicolumn{2}{|c|}{-12.47918} & 8.823966 & -1.414237 & 0.1696 \\
\hline YEAR & \multicolumn{2}{|c|}{0.008494} & 0.004393 & 1.933755 & 0.0645 \\
\hline \multirow{2}{*}{\multicolumn{2}{|c|}{$\begin{array}{l}\text { R-squared } \\
\text { Adjusted R- } \\
\text { squared }\end{array}$}} & 0.740284 & \multicolumn{2}{|c|}{ Mean dependent var } & 4.550034 \\
\hline & & 0.667563 & \multicolumn{2}{|c|}{ S.D. dependent var } & 0.095292 \\
\hline \multicolumn{2}{|c|}{ S.E. of regression } & 0.054943 & \multicolumn{2}{|c|}{ Akaike info criterion } & -2.757820 \\
\hline \multicolumn{2}{|c|}{ Sum squared resid } & 0.075469 & \multicolumn{2}{|c|}{ Schwarz criterion } & -2.395031 \\
\hline \multicolumn{2}{|c|}{ Log likelihood } & 53.50404 & \multicolumn{2}{|c|}{ Hannan-Quinn criter } & -2.635753 \\
\hline \multicolumn{2}{|c|}{ F-statistic } & 10.17983 & \multirow{2}{*}{\multicolumn{2}{|c|}{ Durbin-Watson stat }} & 1.849591 \\
\hline Prob(F-st & & 0.000006 & & & \\
\hline
\end{tabular}

$$
+\beta 4 \mathrm{~T} 1+\beta 5 \mathrm{~T} 2+\beta 6 \mathrm{~T} 3+\varepsilon
$$

Source: Estimation based on the data compiled from RBI Annual Report.

The varying economic conditions from one year to another can also be expected to have an impact on the efficiency of banking sector. Several studies argue that only considering one endogenous break was insufficient and leads to a loss of information when actually more than one break exists [37]. An endogenous structural break test is a sequential test which utilizes the full sample and uses a different dummy variable for each possible break date. Usually, the unit root tests do not suppose more than two structural breaks and this point to some extend is a limitation of unit root testing [63]. At the same time, there are testing procedures which allow one to determine multiple structural breaks in the dynamics of variables. To find the trend, the yearly dummy variable was selected. Using Bai-Perron test the changing trend was overcome by including dummy variables in the model to capture the effects of temporal and efficiency improvement for commercial banks over the period of the study are presented in table 2 .

From the table 2, the break dates were 1997, 2002 and 2006 were determined using the Bai-Perron sequential 
breakpoint methodology, with a maximum of 5 breaks, 5 percent trimming, and a test size of 0.10 . Coefficient covariances for the tests and estimates are computed using White's method with no degree of freedom correction. The R2 was 74 percent and the $F$-statistic are significant and the corresponding probability are all based on a comparison with the full restricted, no breakpoint, constant only model. The $F$ statistic was based on the difference of the sums-of-squares so, despite the presence of White coefficient standard errors, it was not robust to heteroskedasticity. Since the banking industry had been under continuous structural change, the efficiency analysis of the commercial banking system was done at three different points in time namely 1997, 2002 and 2006. Dummy variables for each year, are thus used to account for changes in the banking environment over time.

The break in 1997, witnessed the Reserve Bank switching from a monetary targeting framework to a multiple indicator approach from 1998-99. With effect from October 1997 interest rates on all time deposits, including fifteen days deposits, have been freed. However, the rate on savings deposits remained controlled by the Reserve Bank of India. Lending rates were also decontrolled [1]. CAMELS system of annual supervision was introduced in 1997, and in 1998, RBI judged that this system can fully meet 14 of the 25 Basel Core Principles of Supervision and was implementing compliance with the other 11 core principles. In this process, by $1997-98$, most of the financial market was liberalized. In 1999, Vasudevan committee made an initiative to begin the strategy for computerization of the public sector banks [57]. The Report of the Narasimham Committee (April 1998) provides a framework for the current phase of reforms - the second generation of reforms. In line with the recommendations of the second Narasimham Committee, the Mid-Term Review of the Monetary and Credit Policy of October 1999 announced a gamut of measures to strengthen the banking system.

The time phase during 2002 SARFAESI Ordinance Act enabled banks to attach and sell off pledged assets in case of default, to improve their NPA situation. As per the recommendations of the Narasimham Committee banks cannot recognize income (interest income on advances) on assets where income is not received within two quarters after it is past due. The committee recommended international norm of 90 days in phased manner by 2002. Adequate provision is required to be made for bad and doubtful debts (substandard assets). Detailed instructions for provisioning have been laid down. In addition, a credit exposure norm of 15 percent to a single party and 40 percent to a group has been prescribed. Banks have been advised to make their balance sheets transparent with maximum 'disclosure' on the financial health of institutions [66].

Final break of 2006 coincide with the literature that the phased approach to development of financial markets had enabled RBI's withdrawal from the primary market since April 1, 2006. Further in April 2006, the Reserve Bank issued guidelines on asset-liability management (ALM) to the banks to follow Duration Gap Analysis (DGA) along with the traditional gap analysis for some banks. In line with the policy approach, banks are managing the maturity structure of deposits and loans and investments. They are increasingly mobilizing term deposits in order to provide long-term loans for productive sectors such as infrastructure. The CRR has come down to 6 percent in 2006-07 and the SLR to 25 percent. This step completed the transition to a fully market based system in the Government sector market. According to the recommendations of the Twelfth Finance Commission, the Central Government has ceased to raise resources on behalf of State Governments, who now access the market directly [67]. Further, on the basis of the recommendations of the Steering Committee set up by RBI, Ownership and Governance and the implementation of the New Capital Adequacy Framework were formulated and issued to banks on February 15, 2005. As a result, the restrictions on geographical expansion and ceiling on interest rates were removed [68]. Commercial banks in India started implementing Basel II with effect from March 31, 2007. A study points out the existence of regulatory bottlenecks in the past and their gradual liberalisation in the recent years provide an opportunity to do a natural experiment with performance of Indian commercial banks [28]. There were series of financial crises in Asia, Brazil and Russia, 9/11 terrorist attacks in the US, border tensions, sanctions imposed in the aftermath of nuclear tests, political uncertainties, changes in the Government, and the oil and commodity price shock of 2007-08 [67].

Performance of banking activities is measured in terms of efficiency instead of volume of profits. Among various kinds of efficiencies, technical efficiency is an important one which is defined as the ability and willingness of an economic unit to produce its maximum possible output with given inputs and technology. The first stage involves solving a DEA problem, involving only the traditional inputs and outputs. In the second stage, the efficiency scores from the first stage are regressed upon environmental variables. The sign of the coefficients of the environmental variables indicate the direction of the influence.

Table 3. Regression results of model.

\begin{tabular}{lllll}
\hline Variable & Coefficient & Std. Error & t-Statistic & Prob. \\
\hline C & 4.066612 & 0.418285 & 9.722101 \\
FD & 0.061518 & 0.068686 & 0.895647 & 0.0000 \\
FOG & -0.179313 & 0.023283 & -7.701443 \\
PI & 0.204644 & 0.113884 & 1.796949 & 0.3787 \\
T1 & -0.046938 & 0.061869 & -0.758666 & 0.0000 \\
T2 & 0.118966 & 0.047020 & 2.530093 & 0.4549 \\
T3 & -0.101043 & 0.030684 & -3.293074 & 0.0178 \\
\hline
\end{tabular}




\begin{tabular}{llll}
\hline Variable & Coefficient & Std. Error & t-Statistic \\
\hline R-squared & 0.639499 & Mean dependent var & Prob. \\
Adjusted R-squared & 0.556306 & S.D. dependent var & 0.550034 \\
S.E. of regression & 0.063475 & Akaike info criterion & -2.4905292 \\
Sum squared resid & 0.104755 & Schwarz criterion & -2.173081 \\
Log likelihood & 48.09361 & Hannan-Quinn criter & 2.383712 \\
F-statistic & 7.686970 & Durbin-Watson stat & 2.259599 \\
Prob(F-statistic) & 0.000081 & & \\
\hline
\end{tabular}

Source: Estimation based on the data compiled from RBI Annual Report.

The model summary table 3 reports the strength of the relationship between the model and the dependent variable. The regression accounts for 64 percent of the variance in the dependent variable and the estimated standard deviation of the error term was 0.06 . The standard deviation of the dependent variable $(0.09)$ was larger than the standard error of the regression, so the regression explained most of the variance in efficiency of commercial banks. The DurbinWatson statistics was 2.3 signifying no autocorrelation. The $\mathrm{F}$ value was also found to be significant at one percent level. The predictor presence of foreign banks, T2 (YR2002) and T3 (YR2006) were statistically significant variables that influence the technical efficiency of commercial banks at one percent and private investment had 10 percent level of significance. Fiscal deficits had insignificant impact on the efficiency of commercial banks. It can be claimed that, the $\mathrm{RBI}$ 's primary responsibility was the m monetization of the government's fiscal deficit over of short-term credit, typically non-marketable treasury bills. Further RBI was required to regulate money supply in accordance with inflation and growth objectives. As a result, the institutional arrangements that allowed the government to borrow from the RBI through the issue of ad hoc treasury bills may the reason for the non significance of fiscal deficit on efficiency.

Regarding the impact of foreign bank participation, the coefficient represent that a unit changes in foreign share reflects a decline of 0.18 changes in the efficiency of commercial banks. Researchers argues that the benefits of foreign entry, in terms of improved financial services and regulation should outweigh potential costs such as cream skimming, foreign market dominance, and destabilizing sudden capital outflows [36]. The negative impact might be due to the fact that foreign banks might not have an informational advantage compared to domestic banks and that the share of foreign banks in total banking assets was found to have a positive effect on the real expansion of loans [18]. Ownership structures do not seem to affect margins except for foreign banks, which have a slightly lower margin. The realisation of this positive relationship between the presence of foreign banks and the efficiency of banks may depend on the level of economic development of the host developing country [33]. At a lower level of economic development, banking markets are generally less developed, which means implementing new techniques (introduced by foreign banks) raises costs in the short-run. He argued that the banking industry in India was still underdeveloped, and, therefore, an increased participation of foreign banks has increased costs in the short-run. Many researchers [8, 40, 3 and 60] opined that foreign banks at that stage focused on large corporate customers, notably because of their lack of a branch network and that the presence of foreign banks has a negative relationship with the efficiency of banks. The increased foreign penetration reduces bank margins, thus improving the efficiency of the banking systems [12]. A study [62] measured some influential factors on Islamic and conventional banks in Gulf Cooperation Council (GCC) countries, during the period 2002-2009 and found that foreign ownership does not improve Islamic and conventional banks performance.

Further, banks with extensive exposures to private investment had 0.205 units impact on the efficiency. This can be compared to the study [48] which examined a sample of firms from the Italian manufacturing over the period 19891994 in order to establish whether financial constraints create an incentive for firms to improve efficiency over time. The study indicates that technical efficiency can be affected by the financial resource availability. The results show that structural breaks have significant impact on efficiency. The time period $T_{3}$ (YR2006) and $T_{2}$ (YR2002) showed much improvement in efficiency after deregulation, while $T_{1}$ (YR1997) period had insignificant influence on efficiency. The goal of the assessments was to guarantee the safety and soundness of the financial system by identifying problem $\mathrm{s}$ before the deterioration of financial conditions of banks that may lead to systemic risk.

The phase period from $T_{1}$ (YR1997) showed insignificant result but second reform was to transform the operating environment of the banking industry from a highly regulated system to a more market-oriented one, with a view to increase competitiveness and efficiency. After nationalisation, 90 percent of banking assets were in government owned banks and financial institutions, while entry of foreign banks was restricted which hindered efficient allocation of resources. Financial sector reforms initiated in the early 1990s have attempted to overcome these weaknesses in order to enhance efficiency of resource allocation in the economy. There was need in 1990 to improve the efficiency of banking industry. Besides, inefficiency and lack of competition caused the nonperforming assets in the public sector banks to rise from 14 percent in 1969 to 35 percent in 1990 [67, 53]. This problem had to be tackled during the nineties by undertaking an array of financial sector reforms. The initiation of reforms, in the early 1990s, banks in India found it extremely difficult to face competitive situation. Banks had very limited access to financial markets. Interest rates on both sides of the balance 
sheet were highly regulated. Finally, strict entry barriers severely restricted competition from new private banks [27]. Some study opined that, the period after liberalization did not witness any significant increase in number of efficient banks and some banks have high degree of inefficiency during the period of liberalization [21]. The efficiency of Indian banks has shown a declining trend during the period of deregulation $[49,50]$. The study evaluated the efficiency of the Indian banking system for the period 1986-2000 [32]. They found the deregulation resulted in increase in inefficiency but the tendency for inefficiency to decline over time. India had not been totally insulated from exogenous shocks since the second half of the 1990s which forced for another reform Narsimham Committee (1997) by the Government of India, with a mandate to suggest a programme of banking sector reforms so as to strengthen India's banking system and make it internationally competitive' [67]. The Asian financial crisis of 1997-1999, the importance of balancing financial liberalization with adequate regulation and supervision prior to full capital account liberalization has been increasingly recognized [69]. However banks have still to go a long way to sustain their competitive success. Indian commercial banks also need to enhance their system and procedure to global standards and simultaneously strengthen their financial position.

The time period from $T_{2}$ (YR2002) showed a positive impact of 0.119 unit change on the efficiency, signifying the realization of the objectives of liberalization and the success of both the reforms. While comparing the period before 2002 there was improvement in the efficiency of commercial banks since 2002. As of 2002 the RBI has permitted foreign direct investment in the banking sector up to a maximum share of 49 percent in the bank's should be noted here that interest rate deregulation in India was phased, with several changes implemented in 2000. The policy was one of phased interest rate deregulation and gradual integration of the Indian forex market with global financial markets. By 2000, all other interest rates in the system, except that on small savings, were linked to the bank rate. The studies $[57,26]$ found that all banks however, have started increasing their efficiency levels significantly since 2000 . The enactment of the FRBM Act, 2003 has strengthened the institutional mechanism further. The thrust of banking reforms was not only on the improvement of efficiency through inculcating the spirit of competition among Indian banks but also on strengthening the shock absorptive capacity of the banking system through the adoption of internationally accepted prudential regulations. McKinsey and Company [70] opined that Indian banks adapting to the changing landscape along with the vision of the regulator and the Government in shaping the future growth of banking were two of the noteworthy features of this transition. Banks have evolved their strategies in response to increasing competition and changing customer requirements. The application of technology and product innovations was bringing about a structural change in the Indian banking system and the commercial banks will face new challenges and also new opportunities in the coming years $[55,58,46]$. The reforms have produced favorable effects on performance of commercial banks in general but still there are some distortions like low priority sector advances, low profitability etc. that needs to be reformed [60].

The $\mathrm{T}_{3}$ (YR2006) showed that there was a negative impact of 0.10 unit change on efficiency. In other words commercial banks had faced deterioration since 2006 compared to that of previous years. Since it is predicted that poor macroeconomic performance will lead to poor bank performance, the negative effects on bank performance can be associated with higher unemployment, a faster depreciation in the exchange rate, and a higher inflation rate. Further, a higher growth rate of real GDP should associate with better bank performance. Scheduled commercial banks had implemented Basel II in April 2009 which requires more capital for banks in India for implementing the capital to risk-weighted assets ratio (CRAR) of around 13 percent. The Reserve Bank has issued policy guidelines enabling issuance of several instruments by the banks viz., innovative perpetual debt instruments, perpetual non-cumulative preference shares, redeemable cumulative preference shares and hybrid debt instruments. These temporary reductions will adjust in the long run with better efficiency level. EPW Research Foundation, (2007) reported that the rise in interest rates in 2006-07 has been seen as showing "utter disregard for the development needs" of the Indian economy, with "adverse repercussions for medium and small borrowers", while rendering "in a nonchalant manner large proportions of bank credit to cash-rich corporates at below prime lending rates". Scheduled commercial banks have also made heavy investment in technology during the post-reforms years. Between September 1999 and March 2008, public sector banks incurred an expenditure of Rs.15015 crore on computerization and development of communication networks (RBI 2006).

Banking in India is poised to enter yet another phase of reforms once the door opens further to foreign players in 2009. This requires further improvement in technology management, human resource management and the ability to foresee rapid changes in the financial landscape and adopt quickly [38]. At present, there is a huge hiatus between the top management earnings of state owned banks and private, as well as foreign banks. Banks have to lay down sound risk management strategies and internal capital adequacy assessment committees to ensure that they do not diverge from the prudential requirements. The expansion of the banking sector commensurate with the growth of the economy would not only enhance competition but also facilitate financial inclusion [14].

\section{Conclusion}

This paper aims to provide empirical evidence of the importance to economic growth of the performance of the banking institutions, particularly of bank efficiency, measured through Data Envelopment Analysis (DEA), with 
external environmental factors which include fiscal deficits, private investment and the share of foreign banks. The results confirm that the varying market condition and the presence of foreign banks will contribute positively to economic growth (empirically confirmed by the large strand of literature mostly following the pioneering contribution of King, et al., [30]). The market development kindled by liberalization and globalization has resulted in changes in the intermediation role of banks. While the banking system has done fairly well in adjusting to the new market dynamics, greater efficiency challenges lies ahead.

\section{References}

[1] Ahluwalia, M. S. (1999), "Reforming India's Financial Sector: An Overview, in India a Financial Sector for the Twenty-First Century", (Ed.) J. A. Hanson and S. Kathuria, Oxford University Press, New Delhi.

[2] Alam, I. M. S. (2001), "A Nonparametric Approach for Assessing Productivity Dynamics of Large U.S. Banks", Journal of Money, Credit and Banking 33(1): 121-139.

[3] Ataullah A. and H. Le (2006), "Economic Reforms and Bank Efficiency in Developing Countries: The Case of the Indian Banking Industry", Applied Financial Economics, 16, 653663.

[4] Avkiran, N. K. (2000), "Rising productivity of Australian trading banks under deregulation 1986-1995", Journal of Economics and Finance, Vol. 24, pp.122-140.

[5] Banker, R. D., Charnes, A. and Cooper, W. W. (1984), "Some Models for Estimating Technical and Scale Inefficiencies in DEA", Management Sci. 30, 1078-1092.

[6] Berger, A. N. and Humphrey, D. B., (1992), "Measurement and Efficiency Issues in Commercial Banking, in: Z. Griliches (Ed.) Output Measurement in the Service Sectors", (Chicago: The University of Chicago Press).

[7] Berger and Humphrey (1997), "Efficiency of Financial Institutions: International Survey and Directions for Future Research", European Journal of Operational Research 98:2 (April), 175-212.

[8] Berger and Mester, L. (1999), "What Explains the Dramatic Changes in Cost and Profit Performance of the U.S. Banking Industry," The Wharton School Working Papers \#99-10.

[9] Bhattacharya, P. C. and M. N. Sivasubramanian (2003), "Financial Development and Economic Growth in India: 1970-71 to 1998-1999”, Applied Financial economics, 13(12).

[10] Canhoto, A., and J. Dermine (2003), "A Note on Banking Efficiency in Portugal, New vs Old Banks", Journal of Banking and Finance, 27, 2087-2098

[11] Charnes, A., Cooper, W. W. and Rhoades, E. (1978), "Measuring the Efficiency of Decision Making Units", European Journal of Operational Research, 2, 429-444.

[12] Claessens, S. et al., (2001), "How Does Foreign Entry affect the Domestic Banking Market?", Journal of Banking and Finance, 25, pp 891-911.

[13] Das, A. (1997), “Technical, Allocative and Scale Efficiency of
Public Sector Banks in India". Reserve Bank of India Occasional Papers, 18(2-3): 279-301., June-September.

[14] Deepak Mohanty, Executive Director, Reserve Bank of India delivered at the 5th Indian Chamber of Commerce (ICC) Banking Summit, at Kolkata on May 18, 2013.

[15] Fa“re. R., Grosskopf, S. and Lovell, C. A. K. (1994), "Production Frontiers", Cambridge University Press, Cambridge.

[16] Farrell, M. J., (1957), "The Measurement of Productive Efficiency", Journal of the Royal Statistical Society, Series A, $120,3,253-281$.

[17] Fried, H. O. Schmidt, S. S. and Yaisawarng, S. (1999), "Incorporating the Operating Environment into a Nonparametric Measure of Technical Efficiency", Journal.of Productivity Analysis, 12, 249-67.

[18] Fries, S. and Taci, A. (2002), "Banking Reform and Development in Transition Economies, Working Paper No. 71, European Bank for Reconstruction and Development, London.

[19] Fuentes, R and Carlos Maquieira (2003), "Institutional Arrangements, Credit Market Development and Loan Repayment in Chile", School of Business and Economics, Universidad de Chile

[20] Galagedera, D. U. A and Edirisuriya, P., (2005), "Performance of Indian Commercial Banks (1995-2002)". South Asian Journal of Management, Vol. 12, pp. 52-74.

[21] Ghosh, Saibal, Abhiman (2006), "Financial Deregulation and Efficiency: An Empirical Analysis of Indian Banks during the Post Reform Period", Review of Financial Economics, (Sep), 15(3), 193-221.

[22] Gilbert R A and P W Wilson (1998), "Effects of Deregulation on the Productivity of Korean Banks". Journal of Economics and Business 50, 133-155.

[23] Gupta, O. K., Doshit, Y. and Chinubhai, A. (2008), "Dynamics of Productive Efficiency of Indian Banks", International Journal of Operations Research, Vol. 5, No. 2, pp. 78-90.

[24] Işsk, İhsan, and M. Kabir Hassan (2002), "Technical, Scale, and Allocative Efficiencies of Turkish Banking Industry" Journal of Banking and Finance, 26, 719-766.

[25] Ișık, İhsan, and M. Kabir Hassan (2003), "Efficiency, Ownership and Market Structure, Corporate Control and Governance in the Turkish Banking Industry", Journal of Business Finance and Accounting, 30(9) and (10), Nov. /Dec., 1363-1421.

[26] Izah Mohd Tahir et al (2010), "Cost and Profit Efficiency of the Malaysian Commercial Banks: A Comparison between Domestic and Foreign Banks", International Journal of Economics and Finance, February, vol-2, no-1, pp-186-197.

[27] Jaffry, Ghulam, Pascoe, and Cox (2005), "Regulatory Changes and Productivity of the Banking Sector in the Indian Subcontinent" The Pakistan Development Review 44: 4 Part II (winter), pp.1021-1047.

[28] Kalirajan, K. P. and Shand, R. T. (1994), "Economics in Disequilibrium: An Approach from the Frontier", Macmillan India Ltd. 
[29] Khumbhakar, S. C., A. Lozano-Vivas, C. A. Knox-Lovell, and I. Hasan (2001), "The Effects of Deregulation on the Performance of Financial Institutions: The Case of Spanish Savings Banks", Journal of Money, Credit and Banking 33(1), $101-120$.

[30] King, Robert G. and Ross Levine, (1993), "Finance and Growth: Schumperter Might Be Right", Quarterly Journal of Economics, August, vol. 108, No. 3, pp. 713-737.

[31] Kraft, E. and Tirtiroglu, D. (1998). "Bank Efficiency in Croatia: A Stochastic-Frontier Analysis', Journal of Comparative Economics, 26(2), pp. 282-300.

[32] Kumbhakar, S. C. and Sarkar, S. (2003), "Deregulation, Ownership and Productivity Growth in the Banking Industry: Evidence from India", Journal of Money, Credit and Banking, Ohio State University Press, Vol. 35(3), 403-424.

[33] Lensink, R. and Hermes, N. (2004), "The Short-Term Effects of Foreign Bank Entry on Domestic Bank Behaviour:Does Economic Development Matter?", Journal of Banking and Finance, 28, 553-568.

[34] Levine, R. (1996), "Foreign Banks, Financial Development, and Economic Growth, in: C. E. Barfield", (Ed.) Int. Financial Markets (Washington, DC: American Enterprise Institute Press).

[35] Levine, R and S. Zervos (1998), "Stock Markets, Banks and Economic Growth", American Economic Review, Vol. 88, pp. 537-558.

[36] Levine, R., (1997), "Financial Development and Economic Growth: Views and Agenda", Journal of Economic Literature 35 , pp. $688-726$

[37] Lumsdaine, R. L and. Papell, D. H. (1997), "Multiple Trend Breaks and the Unit Root Hypothesis", Review of Economics and Statistics, 79 (2), pp. 212-218.

[38] Madhavankutty, G. (2007), "Indian Banking - Towards Global Best Practices", Bankers Conference Proceedings (Nov.): 84-86.

[39] Mukherjee, A., Nath, P. and Pal, M. N. (2002), "Performance Benchmarking and Strategic Homogeneity of Indian Banks", International Journal of Bank Marketing, 20(3), 122-139.

[40] Petersen.M and R.Rajan,(1995), "The Effect of Credit Market Competition on Lending Relationships", Quarterly Journal of Economics, 110, 407-443.

[41] Rajan, R. G. and Zingales, L. (1998), "Financial Dependence and Growth", The American Economic Review, Vol. 88, No. 3 , pp. 559-586.

[42] RBI- "The Report on Trend and Progress of Banking in India”, RBI Publication, Various years.

[43] RBI- "Statistical Tables Relating to Banks in India", various years - Annual Publications.

[44] RBI - "Handbook of Statistics on India Economy", various years.

[45] Saha, A and Ravishankar TS (2000), "Rating of Indian Commercial Banks: A DEA Approach", European Journal of Operational Research, 124(1): pp.187-203.

[46] Shroff, F. T. (2007), "Modern Banking Technology", Vol. 4, Banknet Publications.
[47] Sathye Milind (2003), "Efficiency of banks in a developing economy: The case of. India", European Journal of Operational Research, Volume 148, Issue 3, 1 August.

[48] Sena, V. (2004), "The Determinants of Firm Performance: Can Finance Constraints Improve Technical Efficiency?", European Journal of Operational Research.

[49] Sensarma, R. (2008), "Deregulation, Ownership, and Profitability Performance of Banks: Evidence from India", Applied Financial Economics, Vol. 18, No. 19, pp. 1581-1595.

[50] Sensurma Rudra (2005), "Cost and Profit Efficiency of Indian Banks during 1986-2003: A Stochastic Frontier Approach", Economic and Political Weekly, Vol-LL (12), March, 19-25.

[51] Sharma, B. P. (1974), "Role of Commercial Banks in India's Developing Economy", S. Chand and Co. New Delhi,

[52] Sherman, H. D. and Gold, F. (1985), "Bank Branch Operating Efficiency: Evaluation with Data Envelopment Analysis", Journal of Banking and Finance, 9, 297-315.

[53] Srinivasan, T. N., (2002), "Eight Lectures on Indian's Economic Reforms", Oxford University press, New Delhi.

[54] Sturm, J. E.and W. Barry (2004), "Foreign Bank Entry, Deregulation and Bank Efficiency: Lessons from the Australian Experience", Journal of Banking and Finance, 28.

[55] Subbaroo, P. S.(2007), "Changing Paradigm in Indian Banking”, Gyan Management,1(2),51-160.

[56] Uppal, R. K. and Kaur, R. (2007), “Indian Banking Sector: Efficiency in the Post- Banking Sector Reforms Era- New Challenge and Future Opportunities", Prestige Journal of Bank Management and Research, 2(1): 42-55.

[57] Varadi, Vijay Kumar, Mavaluri, Pradeep Kumar and Boppana, Nagarjuna, (2009), "Measurement of Efficiency of Banks in India", - University of Hyderabad, India. MPRA Paper No. 17350, September.

[58] Vashisht, A. K. (2004), "Commercial Banking in the Globalized Environment", Political Economy Journal of India, Vol. 13, Issue 1 and 2, January-June, pp. 1-11.

[59] Vivas Ana Lozano (1997), "Profit Efficiency of Spanish Savings Banks", European Journal of Operational Research, 98, pp 381-394.

[60] Weill, L. (2003), "Banking Efficiency in Transition Economies: The Role of Foreign Ownership", Economics of Transition, 11 (3), 569-92.

[61] Yildirim H. Semih and G. C. Philippatos (2006), "Efficiency of Banks: Recent Evidence from the Transition Economies of Europe, 1993-2000", The European Journal of Finance Vol. $00(0), 1-21$,

[62] Zeitun, R. (2012), "Determinants of Islamic and conventional banks performance in GCC countries using panel data analysis", Global economy and finance Journal, 5(1):53-72.

[63] Zivot, E. and Andrews, K. (1992), "Further Evidence On the Great Crash, the Oil Price Shock, and the Unit Root Hypothesis", Journal of Business and Economic Statistics, 10 (10), 251-270.

[64] Kumar, M., \& Charles, V. (2011). Benchmarking Indian banks in post-reform period using DEA: A progressive-time weighted mean approach. The Service Industries Journal, 14(1). 
[65] Sinha, A. "Internal Banking Crisis and Its Impact on Indian Financial System", BIS Paper (weblink: http://www.bis.org/publ/bppdf/bispap54m.pdf )

[66] Purohit, Venkatesh Mahadevan, and Anjali N. Kulkarni (2012)" Credit Evaluation Model of Loan Proposals for Indian Banks", International Journal of Modeling and Optimization, Vol. 2, No. 4, August.

[67] Mohan Rakesh (2009) "Reforms, Productivity And Efficiency in Banking": IBA Bulle/ill, Special Issue.

[68] Rajan, U., A. Seru, and V. Vig. "The Failure of Models that Predict Failure: Distance, Incentives, and Defaults.” Journal of Financial Economics 115, 2 (2015): 237-260.

[69] Sayuri Shirai(2001), "Mobilizing Domestic Finance for
Development: Reassessment of Bank Finance and Debt Markets in Asia and the Pacific", paper was presented at the ESCAP-ADB Joint Workshop on Bangkok, 22-23 November 2001.

[70] McKinsey and Company (2012),“Global Corporate and Investment Banking: An Agenda for Change" www.McKinsey.com/clientservice/financial_services

[71] Sandeepa Kaur, P. K. Gupta (2015) "Productive Efficiency Mapping of the Indian Banking System Using Data Envelopment Analysis", Procedia Economics and Finance, Volume 25, 2015, Pages 227-238.

[72] Subhash Ray (2016)," Cost efficiency in an Indian bank branch network: A centralized resource allocation model "Omega, Volume 65, December 2016, Pages 69-81. 